\title{
LEGISLATION AND ADMINISTRATION
}

\author{
THE RÔLE OF THE BAR IN ELECTING THE \\ BENCH IN CHICAGO*
}

EDWard M. Martin†

$\mathrm{F}$ IOR MORE than six decades the bar of Chicago has actively interested itself in the election of a well-qualified bench in Chicago and Cook County. This activity is traceable as early as I870, and appeared even before the formation of the present Chicago Bar Association in I874. At various times other groups within the legal profession have exerted themselves in behalf of a better bench, but the Chicago Bar Association has been the principal agency for such action in local matters. In fact, since 1887 the association has almost continuously taken part in judicial elections. Its activity in this respect constitutes a remarkable record of participation in civic affairs.

Two major developments mark this period: $(x)$ the increase in the number of the judiciary and the consequent lengthening of an already too-long public ballot; and (2) the steady growth of local partisan political organizations and a constant extension of their control over judicial selection and administration. These developments have affected both the Chicago Bar Association's method of participation and its influence in the elective process. The writer examines these and related factors at some length in a forthcoming volume. It will perhaps suffice for the present purpose to present the contrasting rôles of the association in the early part of the period and now. Then, it exerted its efforts, in advance of the party conventions, to the end that the party organizations would nominate wellqualified candidates. Now its principal activity is to advise the electorate, after the nominations have been made, concerning the qualifications of candidates sponsored by the party organizations.

Thus after two generations of effort to improve judicial selection in Chicago and with seemingly small tangible results, it is logical to ask, Has the Chicago Bar Association "come to the end of its rope"?

* This article comprises two chapters from the writer's book of the same title soon to be published by the University of Chicago Press. The study was made as a graduate student in the Department of Political Science of the University of Chicago.

$\dagger$ Public Affairs Secretary of the Union League Club of Chicago. 
To the pessimist who limits his vision to the local scene, the answer may seem "yes." But to the person who views Chicago in the national perspective of the rising tide of interest in improved judicial selection, the outlook is more encouraging.

For more than a decade an unspectacular, but persistent, campaign in behalf of better methods of judicial selection has been fostered by the American Bar Association and the American Judicature Society among members of the bar and interested laity. The campaign is now beginning to show results. California's action in I934 may mark the beginning of a new era among the states of experimenting with devices for improving judicial selection. Several other states ${ }^{x}$ have novel proposals under consideration. Slow, but certain, progress in this direction is far from an idle hope.

As the subject of improved judicial selection thus comes to the fore, it is obvious that the long-continued efforts of the Chicago Bar Association have laid an invaluable and necessary groundwork for any concerted action that may be undertaken in Chicago.

The bar and the organizations within the profession are the groups to which the community looks for leadership in these matters. The bar has the economic interest in sound judicial administration to provide the incentive essential for a vigorous public movement. This incentive has been the mainspring of the hundreds of thousands of dollars which have been expended in past campaigns. The business and civic community will continue to cooperate, as in the past, but the organized bar must provide the leadership and the principal support.

The Chicago situation needs two types of activity: (I) activity to raise the level of the legal profession as a whole; and (2) a broad-gauge, longtime program of action effectively to challenge the existing system of selection in its most fundamental aspects.

\section{RAISE THE LEVET OF THE LEGAL PROFESSION}

Many of the desirable objectives have already been enumerated. Some of them lie within the jurisdiction of the bar as now organized and can be attained by its own efforts. Considerable progress might be made, for example, in improving the quality of legal education, in raising the standards of admission to the profession, in formulating standards of professional and judicial conduct; and in enforcing those standards.

An Integrated Bar.-One approach to the problem of a competent bar is the modern development of the integrated or inclusive state bar.

r See the Report of the Committee on Judicial Selection to the Conference of Delegates of the American Bar Association at Los Angeles, I935. 
Associations that are voluntary and selective are obviously limited in their scope and authority. An integrated state bar, such as has been adopted in the states of Washington, ${ }^{2}$ North Dakota, Alabama, Idaho, California, New Mexico, Nevada,'Oklahoma, Utah, South Dakota, Kentucky, Mississippi, North Carolina, Arizona, and Louisiana, ${ }^{3}$ automatically includes all members of the profession and has greater authority over the admission to, as well as the disbarment from, the profession. It would also aid in enforcing standards of conduct and by the application of its sanctions seek to maintain the bar's ancient and honorable traditions for the bench.

Little argument is needed to support the view that if the Chicago Bar Association, under a rule of the Supreme Court, had as much authority over admissions as it does over expulsions 4 from the profession, it would be enabled to aid materially in raising the general average of the profession and thus eventually heighten the level of the bench. If a unified bar plan were adopted for Illinois, the Chicago Bar Association or the group of attorneys comprising it, would predominate in determining policies affecting Chicago.

\section{STANDARDIZE THE QUALIFICATIONS DEEMED DESIRABLE IN A JUDGE}

The almost total lack of any definite basis, other than custom or arbitrary opinion, for determining what qualifications a judge should possess, directs attention to a profitable field of inquiry. An investigation which would derive a definite statement of the qualities deemed desirable in a judge would tend to facilitate the work of the association and to simplify the problem of selection. Candidates for the bench could be rated in terms of standards thus formulated. The association's task of appraising candidates would be simplified. Its recommendations would tend to become more and more based on demonstrable fact, instead of opinion supported by information known only to its committees.

Recent progress in appraising human aptitudes and capacities suggests that an application of analytical techniques to the wealth of information in the association's files could improve the system of grading candidates

$=$ The Washington State Bar Act, for example, authorizes the board of governors, subject to the approval of the Supreme Court, to control the entire matter of admission to practice, including the appointment of examining boards or committees. The court retains, however, power to admit or reject any applicant who has taken the examination. Annual Review of Legal Education 30 (I933).

3 See I8 American Judicature Society Journal I66 (r935) for states with integrated Bars and dates of adoption. See $i d$., I70-72, for legislative review of integration movement in 1935 .

1 See I 7 id., 2I (r933) for explanation of rule of the Illinois Supreme Court adopted April 2I I933. 
which the association has already developed. To the material already on hand could be added information concerning the record of successful candidates on the bench. Comparison could then be made between these two sets of information and tentative conclusions could be reached as to the qualifications thus shown to be related to judicial ability. Many individual instances covering many years would furnish a wide basis for these conclusions.

Assuming that such tests are possible, would they be feasible? We have already mentioned the added advantage to the association. Some sticklers for the political proprieties would be sure to resent any such infringement of popular liberty. The candidates would probably not object. They now submit to many tests that are as much or more galling to their pridetests of political availability and feudal subservience to "the organization." They now voluntarily undergo the association's questionnaire inquiry and the cross examination before the committee on candidates.

The association, of course, would proceed unofficially in developing such standards. Its efforts would become effective to the extent that the standards stood on their own merit and in the measure that they enlisted public support in the movement for a better bench. If the association were successful in developing reliable tests of judicial fitness, they might eventually become statutory requirements for judicial office in the same way as the minimum requirements of age, residence, and length of professional experience are now written into the law of many states.

\section{INTENSIFY THE RÔLE OF THE BAR}

With increasing emphasis, Chicago's judicial elections in I933, I934 and 1935 have made it embarrassingly obvious that the bar association must modify either its traditional rôle or the established method of selection, or both, if it is ever to cope with conditions in Chicago we have described in the previous pages. As one writer, discussing the Chicago situation, has patently remarked:

The bar primary is admittedly only temporizing with what informal opinion at the bar recognizes as an evil, the selection of judges by partisan or unguided non-partisan choice. It is only an effort to make the best of a bad situation.s

Another authority criticized the association to the writer for "allowing itself to be euchred into supporting unfit candidates."

It is clear that under an evenly-divided bipartisan system of selection, such as Chicago has in theory, the bar association by holding a balance of

5 J. M. Landis, New York State Bar Association Bulletin, no. IV, Ig8 (I932). 
power has been able to influence judicial selection as an advisory, secondary participant in the process.

But when the system goes askew under the leadership of dominant, shifty, calculating, private-interest politicians, the association is left literally high and dry. Its recommendations, be they derived with all the care and ingenuity known to man, fail of accomplishment, not because of inherent weakness, but simply because they fail to carry weight (I) with the political leaders who operate the system of selection and (2) with a large element of the electorate which the same political leaders control at the polls.

Only by challenging the established system at its roots can the bar association bring its influence in judicial selection to bear. Under existing conditions the bar primary and the ensuing publicity campaign are merely temporizing with surface indications. Structural changes are needed that will cut the lines by which the party leaders now control the selective process. These changes will come under the leadership and tutelage of the organized bar.

The proposal for an elective chief justice empowered to appoint his associates, in the writer's opinion, would go far to accomplish this purpose in the Municipal Court. It would tend to minimize the dominant position of the party leaders and would definitely establish the bar as an essential part of the selective mechanism. The bar primary-the traditional means of expressing the consensus of the bar-is regarded an integral aspect of this proposal. The suggested plan, furthermore, would simplify the matter of judicial candidacies and would give greater effect to the bar's recommendations.

While the bar primary is admittedly a cumbersome method and subject to the limitations of any mechanical plan, its value as a poll of the active members of the bar and as a sanction for the recommendations concerning candidates must not be overlooked. That sanction, in the writer's opinion, is the most convincing reason to the lay voter why he should seriously consider or heed the advice of the bar. The bar primary plan has been criticized on many scores. Much of the comment has been aimed at the mechanical details of the plan. In point of fact for many years past the bar association has been the only agency (outside the party organizations) in metropolitan Chicago giving attention to the problem of judicial selection. From the viewpoint of the individual elector, the problem begins at scratch and any advice from an informed source is sheer gain. The problem of epitomizing the opinion of any group of experts, whether it is half a dozen or several hundred, is largely a matter of mechanics. The associa- 
tion has sought to improve its bar primary plan to make it a true consensus of its active members. There is a feeling, however, that frequently, particularly in the Municipal Court polls, the candidates are not sufficiently well known to enable the members of the association to vote from personal knowledge of their qualifications.

The proposed plan to elect the chief justice and empower him to appoint his associates, together with the provision for candidates to "run on their record," would meet this situation in part. Candidates for the chief justiceship and the incumbents seeking renewal of their terms would be well known to every alert member of the bar. The plan for the bar to participate directly in the process of nominating eligibles for the associate justiceships might develop candidates of greater experience than those produced under the present system.

Educate the Electorate.-By far the greatest need in the Chicago situation is the matter of acquainting the general electorate with the inadequacies of the present scheme of judicial selection and winning its support for a sound plan to improve the system. Such a plan should be accompanied by a program of public education. It should deal with fundamental principles and should be divorced from the personal issues of any election campaign. The plan will have to be developed into a public issue on which the political groups can take sides. To do this will require months, perhaps years, of persistent, intelligent labor in coaxing public support to the new point of view.

Organize an Ally.-Since the major part of any remedial program will consist in modifying existing laws and customs, the bar association will need the cooperation of the non-partisan and civic forces in the community at large. For this reason it is suggested that the association take a leaf from Ben Franklin's book of tricks and organize an ally to be the spearhead in the program. This ally should consist of lawyers and laymen who could organize the machinery of winning public support for the plan and principles of sound judicial selection laid down by the bar.

The modern bar association is devoted primarily to advancing the interest of the legal profession. The selection of judges is thus only one of many matters receiving attention. Furthermore, a bar association is neither a political party nor a crusading society. Both of these attributes are needed in the effort to obtain the adoption of the program herein suggested, especially against the experienced and organized political opposition presented in the Chicago situation.

It seems unlikely that the Chicago Bar Association as such would or could successfully champion a thoroughgoing program of reform. Its 
membership is too large and representative of too many personal points of view ever to present the united front needed to succeed in such a venture. Many of its members are so closely linked to the political hierarchies that any serious attempt to depoliticize the courts would surely bring a violent reaction within the association. Moreover, the association's policy of changing its leaders annually, or at least biennially, introduces an element of discontinuity which is fatal to a campaign which may require years to complete. Perhaps the greatest handicap is that political activity is incompatible with the major objects of the association. If its efforts were occasionally victorious, this type of activity might rise in importance. It could occasionally "point with pride." But when strenuous efforts persistently meet defeat, as in Chicago, the activity becomes an expensive embarrassment.

The organization of an ally of the type suggested would avoid many of these difficulties. This ally would not be too much fettered by professional conventionalities. It would be free to act in any ways desired on its own responsibility. It would be devoted solely to the application, extension and support of the principle of improving the selection of judges in Chicago. The members of the association and of the bar, with the cooperation of the business and civic elements of the community, could initiate and support such a body. It would draw to it support from other elements in the community which now only passively cooperate with the association. The association, in fact, could act as the expert adviser to this allied, but independent agency which would be free to engage in propaganda, political or other activity necessary to secure the adoption of the desired objectives.

In this matter the association should take a leaf from its own book of experience. The history of the Committee for the Election of Good Municipal Judges in Igo6 is suggestive of the type of organization which can be formed and through which the association can advocate the adoption of its principles of judicial selection.

The rôle of the bar in judicial selection must be many-sided. Not only must it lead, and prove worthy of such leadership and confidence, but it must prepare the way and establish the goals, and it must rally the forces of democracy to a vigorous defence of their own interests.

THE ATTITUDE OF THE VOTERS AS A FACTOR AFEECTING THE INELUENCE OF THE CHICAGO BAR ASSOCIATION

The desirability of a favorable attitude on the part of the voters toward the Chicago Bar Association in determining its influence in judicial selec- 
tion is too obvious to need elaboration. It is important, therefore, to inquire what attitudes various elements in the electorate have indicated, what their voting strength is and what likelihood there is of their acting on the association's advice.

The writer has attempted to estimate ${ }^{6}$ the voting strength of various elements in the Chicago electorate. The electorate includes elements representing the primary human cleavages which are based on nationalistic, racial, religious and economic interests. On account of concentration into definite constituencies, groups having these cleavages have great political strength. This strength is capitalized by the organization leaders in "building up" party tickets.

\section{WHO ARE THE ELECTORATE?}

In I932 only 77.9 per cent of the persons legally eligible to register (i.e., qualify for voting) in Chicago were actually enrolled on the election poll books. This fact of itself is significant, for at a time when popular interest in elections was at a peak, more than 400,000 persons, or more than onefifth of the adult citizenry, had failed to qualify as electors. The margin required for a political organization to win at the polls was thus narrowed. Since this inactive element of the potential electorate is presumedly "independent" politically and therefore the type of citizen to whom the nonpartisan advice of the bar association should appeal, the association's field of action was accordingly narrowed.

Nationalistic and Racial Elements. - While there were 1,226,89r nativeborn white adults, or $8 \mathrm{I} .9$ per cent of the registered electorate, only 506,245 of this number, or one-third of the electorate, were truly "native" Chicagoans (i.e., native born of native parents). The aggregate constituencies of foreign extraction comprise 82.4 per cent of the Chicago electorate.

${ }^{6}$ Basis of estimates: Computed strength of the electorate: $2,209,5^{\mathrm{r}} 4$ persons $2 \mathrm{I}$ years and over, minus 286,999 (foreign-born whites with first papers, plus $168,8 \mathrm{I}_{5}$ aliens and $2 \mathrm{r}, 939$ unknowns-all ineligible to vote) equals $I, 922,515$. Source: United States Census, I930, III, Part I, p. 628.

Source of data regarding actual registration: Chicago Daily News Almanac, 735 (I933).

Source of data for native and alien-born population: United States Census, r930, III, Part I, p. 628.

Computation of estimated strength of foreign groups as follows: Data on all ages for "foreign-born whites" and "native whites of foreign or mixed parentage" were totaled, and then were multiplied by the percentage factor 65.44 which represents the ratio of population 21 years and over to the entire population in Chicago. Source: United States Census, I930, III, Part I, pp. 638-44. Estimate for Jewish is from United States Census of Religious Bodies, rg26, p. 389 , similarly modified.

Sources regarding religious bodies from United States Census, 1926, p. $3^{69}$. 
The United States Census distinguishes more than thirty nationalistic and racial groups in Chicago. Nine of these have a potential voting strength in excess of 75,000, as follows: Polish, German, Jewish, Negro, Scandinavian (grouping Norwegians, Swedes and Danes together), Irish, Italian, Russian and Czechoslovakian.

Religious Groupings.-Dividing the religious elements into Roman Catholic and other-the Roman Catholics are estimated to have had in I 926 a voting strength of 548,000 persons or $3^{6.7}$ per cent of the eligible electorate. Ten white Protestant sects, with 588 church units, had a voting strength of $\mathrm{I} 79,394$ persons or $\mathrm{I} 2$ per cent of the registration.

Labor.-The importance of the "labor" element in Chicago politics is indicated by the number of "workers" which in I930 was estimated at I,330,000. The Chicago Federation of Labor, the active, organized element of this group, contained 293,546 members or nearly 20 per cent of the city's entire voting strength. In addition to the common ties of unionism, the "labor" group has the solidifying agencies of a central organization, a weekly journal and a radio station.

Civic Groups.-The element of the Chicago population aligned with so-called civic or public purpose organizations is suggested by information published in I927. More than 430,000 (excluding the Federation of Labor) were reported to be affliated with city-wide groups and 257,000 had membership in local community organizations. While the number of such memberships changes from year to year and varies with the economic status of the community, the conclusion can be drawn that a considerable part of the population is affiliated with some organized "civic" movement, using that term in its broadest sense. This element, however, is utterly lacking in unifying agencies.

\section{INDICATIONS OF THE VOTERS' ATTITUDES TOWARD THE BAR ASSOCIATION}

Obviously, any attempt to indicate what attitude a large group of voters has toward the bar association is a hazardous undertaking. It is possible, however, to obtain suggestive inferences and expressions of individual opinions which indicate in a general way whether the attitude of a group is favorable or unfavorable.

Nationalistic, Racial and Religious Groups.-The traditional solidarity that characterizes the great nationalistic, racial and religious groups justifies the inference that in a political contest the members of these great constituencies would vote for a member of their own race, nation, or religion first, regardless of whether he had bar endorsement, and for a bar en- 
dorsee or any outsider, second. This is almost an aphorism of the political jungle. It motivates all political planning, slate building, campaign strategy, etc. Emotional ties of blood, heritage, locality, or belief are stronger than the intellectual bonds of impartial appraisal of fitness even for so important an office as the judiciary.

Instances can be noticed of appeals along racial and nationalistic lines in the foreign language newspapers. ${ }^{7}$ While instances were cited where editors had regarded the bar's recommendations as valuable sources of information that should be considered, and while it is hazardous to generalize, the tendency among voters in these constituencies is either to disregard the association's advice or to take a frankly hostile attitude, especially if a "favorite son" has not been endorsed. In fact, there are instances of candidates making political capital among special constituencies out of the withholding of bar endorsement.

An inkling of the Negro attitude toward the association is given by the following communication addressed to it during the I933 election by the Chicago Branch of the Association for the Advancement of the Colored People:

Some time ago we registered with your organization a protest against the exclusion policy maintained in respect to the admission of qualified Negro members of the Bar. At this time (June I, I933) we register protest against the incursion of representatives of your organization into the Negro district asking support of candidates endorsed by you for the Judiciary.

We feel that the axiom- "He who comes into equity must come with clean hands" -obtains in this case. We have advised all churches and their pastors of the attitude of your Association toward Negro members of the Illinois Bar, and while we feel that some of your recommendations may be good, we also feel that you should not place your recommendations on the high ground of "social justice and purity" when you are so obviously unfair, un-American, and devoid of social purity in the matter of admission of Negroes to your organization.

We register this protest with you and have taken the action that we have in advising all Negro ministers, and many white ministers who are liberal and fair, because we are truly and sincerely interested in "social justice."

While the association has been charged with being "a hotbed of antisemitism," it is doubtful if this view characterizes the Jewish group as a whole. The Jewish press tends to adopt the provincial nationalistic viewpoint when a choice is presented between an unendorsed "favorite son" and a candidate approved by the association. On the other hand, a considerable number of the association's members are Jewish and to the writ-

7 See the chapter on the Press, in the author's book, The Rôle of the Bar in Electing the Bench in Chicago, soon to be published by the University of Chicago Press. 
er's knowledge more than one Jewish organization has cooperated in the association's campaigns.

So far as is known, the Chicago Church Federation (Protestant) is the only religious body that has actively evinced interest in the association's projects. In 1933 it gave collateral cooperation through its commission on political action. The pastors were requested to offer prayer from their pulpits for the success of the "right" candidates. Church clubs and societies have distributed the "marked ballots." On the morning of election day, June 5, I933, many Protestant churches in all parts of Chicago rang their bells to remind the community to go to the polls, the assumption being that the church members would vote for the "right" issues on the ballot-non-repeal candidates for the state convention and the "Bar Association ticket" for the judiciary. Two hundred thousand marked ballots were also distributed by women's organizations in one thousand churches.

Labor. - While the Chicago Federation of Labor in recent years has not come out openly against the association, in the Igog Circuit Court campaign, the federation endorsed a full ticket for the reason, explained by John Fitzpatrick, its president, as follows:

We did not intend to endorse anyone until the Bar Association raised the issue. That body, which furnishes the lawyers to the corporations that are fighting organized labor, has seen fit to endorse the injunction judges and to condemn the men in whom labor has a friendly interest. If that is to be the issue, we ought to meet it fairly and not allow the Bar Association to elect the judges in this county. ${ }^{8}$

Civic Agencies.- The attitude of certain groups may be inferred by the cooperation which they have given in financing the association's publicity campaigns and in distributing marked ballots to their members. In the I933 contest, for example, it is known that nearly one-half of the campaign fund was contributed by laymen and business interests. We may also recall that one hundred forty-seven firms, almost all of which were probably affiliated with the Chicago Association of Commerce, distributed 60,000 marked ballots among their employees. One hundred thirty civic and lay groups distributed more than 100,000 marked ballots to their members. A woman's campaign committee distributed 234,785 ballots to women's organizations.

But as a rule it can be shown that such special interest is the direct result of educational work carried on in advance of the campaign. For example, the Union League Club, the Rotary Club of Chicago, the City $\mathrm{Club}$, and the Chicago Woman's Aid have adopted resolutions endorsing in principle the plan of distributing in advance of each primary or election

${ }^{8}$ Chicago Daily News, May I7, I909. 
the association's recommendations as non-partisan information for their members. Each resolution was careful to declare, however, that the organization itself did not recommend candidates. ${ }^{9}$

Organizations which have distributed the recommendations in one or more campaigns have included: The Chicago Association of Commerce, the Woman's City Club, the Chicago Woman's Club, the Cook County League of Women Voters, Union League Club, Better Government Association, the Voters' Clearing House, the Christian Citizenship Council, and the Fifty-fifth Street Business Men's Association.

As in the case of certain newspapers, organizations have occasionally taken the Bar Association's list as a starting point and have made exceptions to its slate for stated reasons. Thus, on May I9, I933, the action of the Chicago Real Estate Board was announced as recommending "a slate of judicial candidates identical with the endorsements of the Chicago Bar Association except in two instances."

While some groups are willing to cooperate to the extent of presenting the recommendations as information in a specific campaign, ${ }^{\mathrm{Ix}}$ many more hesitate to adopt the plan as a permanent policy.

9 Resolution adopted by the Union League Club of Chicago at special meeting January 22, I93I:

"To combat crime and to secure the proper administration of both civil and criminal justice, it is essential to elect judges of the highest character and ability. To this end, the voters should have reliable information concerning judicial candidates.

"Such information can be obtained from the Chicago Bar Association. The lawyers know the candidates and want good judges before whom to try their cases.

"The Chicago Bar Association, prior to each judicial primary and each judicial election, makes, through competent committees, a thorough investigation of each candidate. It mails to its members a printed report giving information about each of them. It then determines, by a secret ballot of its members, what candidates shall be recommended to the voters. Its recommendations are always non-partisan.

"The Union League Club does not recommend candidates for public office. It believes, however, that for voters who have no personal knowledge of judicial candidates, the recommendations of the Chicago Bar Association are the safest guide. It believes that the widest publicity should be given to these recommendations. It believes that when their value comes to be understood by the voters we shall elect more of the better class of judges.

"Therefore, BE IT RESOLved that before each judicial primary and before each judicial election, this Club send to every resident member a copy of this resolution, together with a copy of the recommendations of the Chicago Bar Association."

so Chicago Tribune, May I9, r933.

Ix Following is an incomplete list of speaking engagements filled by the Bar Association in the Municipal Court election of November 8, x932: October I2, Auburn Park Improvement Association; I7, Olivet Institute, Women's Club (Board of Managers); r8, Better Government Council; I9, House of Happiness; 20, Emerson House; 21, Cook County Federation of Women's Clubs, Southwest League of Women Voters; 24, Chicago Church Federation (Committee on Civic Relations), Conference of Jewish Women, Independent Unemployed 
Even more instructive than cases of cooperation, are instances personally known to the writer of lack of interest, refusal to cooperate, and obvious side-stepping of the issue out of friendship for candidates not endorsed by the association. Several groups to which the matter of cooperating with the bar association was presented in writing, tabled the proposition; in one group, due to the influence of a political office holder, it was sidetracked as "political action." Offers to supply speakers or "marked ballots" to several organizations were unanswered. In another case, an endorsement in principle was requested from the individual members of a law faculty, but was withheld on the ground that several of the members favored the re-election of an incumbent judge whom the association had denounced as unfit. At the same time, in another institution the law faculty signed and, at their own expense, circulated an endorsement of the recommendations to the entire university staff. In one case the head of an organization, a member of the association, undertook to induce his associates to consider the matter as a policy of civic action. He gave the plan his personal endorsement, but the group failed to act.

From this somewhat sketchy survey of the interest of organized groups in the association's efforts, it is evident that there are numerous organizations ready to "go on record" and to support the association in successive campaigns; many groups are also willing to have speakers present the issue to their members and many are willing to distribute ballots. But the failure of many groups to respond indicates a prejudice against the type of cooperation desired. In several years of contact with civic groups the writer has found that unless a group has been organized for the specific purpose of sponsoring or supporting candidates, or of pronouncing upon the qualifications of candidates in the same way as the bar association passes upon aspirants for the bench, it usually will studiously avoid any action that can be construed as "political." The reasons for this are probably one or more of the following: (I) the organization was founded to

Aid Association; 25, Woodlawn Business Men's Association, Hell N'Maria Club, Northwest Lions Club; 26, Chase House, Woman's City Club (Gage Park Branch), Woman's City Club (49th Ward Branch); 27, Lake View Lions Club, Lincoln Park Community Forum; 28, Marquette Community Association, Fort Dearborn Round Table, Better Government Club, Woman's City Club (48th Ward Branch); 3r, Woman's City Club (34th Ward Branch), Chicago Church Federation, Union League Club, Hyde Park League of Women Voters; November I, Wicker Park Women's Club, Rotary Club of Chicago, Berwyn (IIl.) Ist Congregational Church, Council of Jewish Women, City Club; 2, Howard Street Business Men's Association, Church Meeting; 3 Northwestern University Settlement; 4, Chicago Commons, Ridge Young Voters' Forum; 7, Morgan Park Improvement Association; 2I, Loyola University Law School. 
promote policies, not personalities; (2) an organization as such cannot participate in politics, but its members may do so as individuals; (3) the emotional "feeling" which the personal rivalries of partisan contest engender may endanger the solidarity of "non-partisan" organizations; (4) it is embarrassing to be defeated-and the odds are against victory, when you are pitted against the political machines; (5) "politics is rotten"; (6) "we can't be bothered"; (7) "we can't commit our organization for the future."

The attenuated reasoning of the association's appeal, the impersonal character of its plea, and the non-partisan traditions of organizations which are otherwise sympathetic, are also considerations which result in the hesitant attitude of many groups toward the association's recommendations.

The groups which have cooperated in past campaigns contain only a minor fraction of the total vote. The attitude of such groups could be an important aid in extending the association's influence. Although the groups now lack unity, their aggregate membership is numerically great. Their widespread existence over the city and their personal, "town meeting" contact in the majority of local communities contains the basic support necessary to the sustained success of any civic movement. In effect, it could become truly the life blood of the present idealistic skeleton.

THE VIEWS OF INDIVIDUAL CITIZENS

On the assumption that non-partisan civic groups would at least be "sympathetic" toward the bar association's efforts, the writer addressed a letter and inquiries to the presidents and secretaries of 875 civic groups ${ }^{12}$ to ascertain their ( $I$ ) interest in the election of a well qualified judiciary, (2) their information concerning the objectives of the Chicago Bar Association, and (3) their disposition to follow the association's recommendations.

Two general inquiries were made: (I) The various sources from which the person received useful information concerning judicial candidates and (2): (a) "Do you now use the Bar Association's recommendations?" and (b) "Would you be guided by them if the information were more easily available?" As a final point, the person's ideas were invited concerning better ways to inform the voters regarding the qualifications of candidates for judicial office.

From I,750 letters mailed, of which $4 \mathrm{I}$ were returned as undeliverable,

${ }^{12}$ See the Chicago Daily News Almanac and Year Book 847-72 (r93I). 
a total of $4 \mathrm{I} 8$ replies was received. ${ }^{33}$ This was a net return of 24.5 per cent. Considering the fact that only one letter was sent, with no "followup," and that the writer was a total stranger to about 99 per cent of the persons, the number of replies was gratifying.

Sources of Information.-Only slightly more than one-half of these $4 \mathrm{I} 8$ citizens consciously obtained their information regarding candidates from

\section{TABLE I}

Sources of INForatation of SELECT LIST OF 418 CitIzens CONCERNING Qualificattons of Judictal Candidates

\begin{tabular}{|c|c|c|}
\hline \multirow{2}{*}{ SOURCE OF INFORMATION } & \multicolumn{2}{|c|}{$\begin{array}{l}\text { INDICATIONS OF SPECI- } \\
\text { FIED SOURCE }\end{array}$} \\
\hline & Number & $\begin{array}{l}\text { Percentage } \\
\text { of Total }\end{array}$ \\
\hline 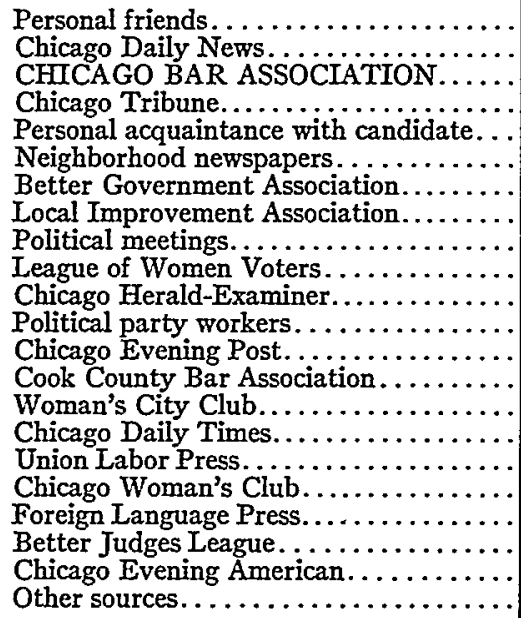 & $\begin{array}{r}235 \\
234 \\
226 \\
218 \\
198 \\
110 \\
102 \\
100 \\
99 \\
70 \\
65 \\
59 \\
49 \\
48 \\
38 \\
23 \\
22 \\
22 \\
18 \\
13 \\
7 \\
55\end{array}$ & $\begin{array}{r}56.2 \\
56.0 \\
54.1 \\
52.2 \\
47.4 \\
26.3 \\
24.4 \\
23.9 \\
23.7 \\
16.7 \\
15.6 \\
14.1 \\
11.7 \\
11.5 \\
9.1 \\
5.5 \\
5.3 \\
5.3 \\
4.3 \\
3.1 \\
X .7 \\
I 3.1\end{array}$ \\
\hline
\end{tabular}

the bar association (see Table I). While some of the twenty other sources indicated derive their views in part from the association, it is significant that only 54 per cent of them were evidently enough aware of the asso-

${ }^{13}$ Result of questionnaire inquiry to selected list of citizens regarding their attitude toward the bar association:

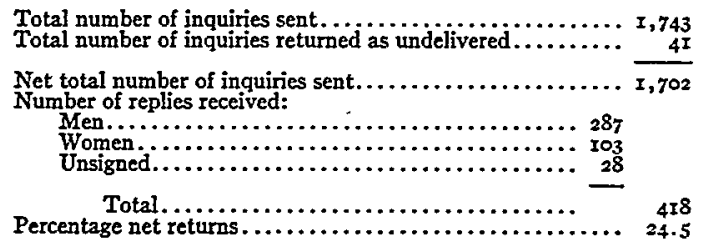


ciation's practice of endorsing candidates to identify it as a source of information at election time.

The figure of 54.I per cent (those who consciously received information from the bar association's recommendations) is roughly confirmed by the direct questions: "Do you use the bar association information?" and "Would you use it if you had it?" These questions more effectively disclose the attitude of these citizens towards the association. Thus while $6 \mathrm{I}$ per cent used it, Io per cent of the number qualified their replies and 3 I per cent gave an adverse verdict. The replies to the second part show a shrinkage in comparable questions, but this may be accounted for in part by the larger number who evidently believed the two questions had no essential difference and therefore failed to reply to Part "B."

As a means of approximating the essential intent on the specific point of their attitudes toward the association, the two sets of replies were tabulated for corresponding points of the two parts. These comparisons are presented in section "C" of Table II. Thus, I99 persons replied "Yes" to both A and B; 40 replied "Yes" to A and left the "Yes" of B blank; 32 said, in effect, that they did not use bar advice, but would do so if they had it, etc. On this basis the total number of favorably disposed citizens was 283 , or 69 per cent, while I Io, or 26 per cent, were disposed not to accept bar advice and 25, or 5 per cent, apparently weren't acquainted with the activity at all.

The fact that more than one-fourth of the voters in a group reasonably supposed to be at least "sympathetic" to the association's objectives were definitely antagonistic is truly amazing. This led to a more detailed analysis of the replies.

Nearly one-half of the replies included a written comment. Many of these disclosed the person's attitude toward the association. Others gave their suggestions for improving the means of selecting judges or of appraising the qualifications of individual candidates.

Confidence in the Bar.-Eighteen persons expressed confidence in the association in the following terms:

$a$. Four persons affirmed their confidence in the "published reports by Chicago Bar Association."

b. "Chicago Bar Association has always been fair with its recommendations," was the opinion of six persons.

c. "Recommendations of the bar association are the most reliable to be found. Easily available in leading newspapers."

$d$. "The bar association is reliable, and should give its opinion over the radio." 
$e$. "The bar association should be the one to select among their members, legitimate and competent men, answerable only to them."

$f$. "The bar association should put its stamp of approval on the candidates, but should not have the right to name the candidates."

g. "Candidates might be selected by Chicago Bar Association instead of by political party leaders. If elected, such jurists would be free to exercise their good judgment as might be befitting."

\section{TABLE II}

Atritudes of 418 Officers of Civic Agencies toward tee Chicago

BAR Assoctation's RecoMarendations CONCERNING Judictal CANDidates

\begin{tabular}{|c|c|c|c|c|c|c|}
\hline \multirow{2}{*}{ Group } & \multicolumn{3}{|c|}{ NUSBBER OF REPLIES } & \multicolumn{3}{|c|}{ Percentages } \\
\hline & Men & Women & Total* & Men & Women & Total \\
\hline $\begin{array}{l}\text { A. Already using information. } \\
\text { Total................... }\end{array}$ & 287 & 103 & $4 \mathrm{I} 8$ & & & \\
\hline 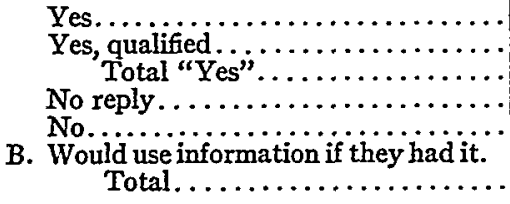 & $\begin{array}{r}140 \\
30 \\
170 \\
22 \\
95 \\
287\end{array}$ & $\begin{array}{r}52 \\
\text { II } \\
63 \\
\text { II } \\
29 \\
\text { I03 }\end{array}$ & $\begin{array}{r}212 \\
42 \\
254 \\
34 \\
130 \\
4 \times 8\end{array}$ & $\begin{array}{r}49 \\
\text { 10 } \\
59 \\
8 \\
33\end{array}$ & $\begin{array}{l}50 \\
\text { II } \\
6 I \\
\text { II } \\
28\end{array}$ & $\begin{array}{r}5 I \\
\text { IO } \\
6 I \\
8 \\
3 I\end{array}$ \\
\hline 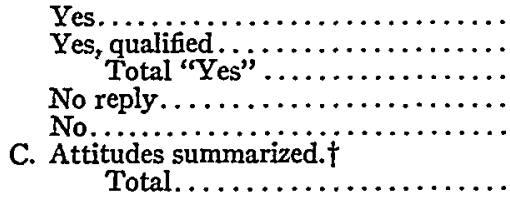 & $\begin{array}{r}\mathrm{r} 33 \\
22 \\
\mathrm{r} 55 \\
47 \\
85 \\
287\end{array}$ & $\begin{array}{l}58 \\
12 \\
70 \\
18 \\
\text { I5 } \\
\text { I03 }\end{array}$ & $\begin{array}{r}207 \\
35 \\
242 \\
69 \\
107 \\
418\end{array}$ & $\begin{array}{r}46 \\
8 \\
54 \\
16 \\
30\end{array}$ & $\begin{array}{l}56 \\
12 \\
68 \\
17 \\
15\end{array}$ & $\begin{array}{r}50 \\
8 \\
58 \\
16 \\
26\end{array}$ \\
\hline 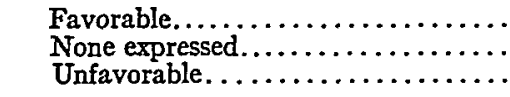 & $\begin{array}{r}182 \\
17 \\
88\end{array}$ & $\begin{array}{r}8 \mathrm{I} \\
8 \\
\mathrm{I} 4\end{array}$ & $\begin{array}{r}283 \\
25 \\
110\end{array}$ & $\begin{array}{r}63 \\
6 \\
31\end{array}$ & $\begin{array}{r}79 \\
8 \\
13\end{array}$ & $\begin{array}{r}68 \\
6 \\
26\end{array}$ \\
\hline
\end{tabular}

* Includes 28 unsigned replies.

† This summary is based on the replies to both questions A and B above.

$h$. "Give bar association findings as to all candidates-but not the bar's primary vote."

$i$. "Let bar association's committee survey the acts of all Cook County or Municipal Court judges with the same fearlessness exercised by the statisticians of the Municipal Voters' League."

$j$. "Have bar association recommendations more widely published in the press." 
Distrust of the Association.-Twenty-two persons were frankly distrustful of the association's recommendations. Ten of these based their view on the association's failure to endorse Judge John H. Lyle in the preceding election (November, r930). They said:

a. "Give us more Judge Lyles," demanded two dissenters.

b. "Use case of Judge Lyle" was the declaration of distrust from one person.

c. "Need more like Lyle. Chicago Bar Association does not recommend him," was the sentiment of five others.

$d$. "Adopt the same methods used by Judge Lyle who is out for the interest of the people regardless of party affiliations."

$e$. "The bar association should wake up to the fact that a strict interpretation of the law is not the wish of the majority nor to the best interests of our country. Refer to Judge Lyle."

Other expressions attesting lack of confidence in the recommendations were:

a. "Action of bar association in the past does not justify full confidence."

b. "Bar recommendations are very narrow. It views the candidate in a legal way only."

c. "It should give unbiased opinions upon the individual candidates regardless of political parties."

d. "As it is today, each member of the bar association chooses to favor for election the judge who would favor him in his profession at the court."

$e$. "The better and abler men in the bar are too busy or uninterested to vote in the bar recommendation elections and leave it to a few who use the bar to further their own selfish interests."

$f$. "If the civic agencies didn't have some axe to grind, the public would have more confidence in their choice."

g. "Information about candidates is not sufficiently candid and outspoken."

h. "I should like to have confidence in the bar association's recommendations but find that the candidates for judges are in the habit of canvassing members of the bar to get their vote. I have heard lawyers say they "could not refuse their consent, mainly for business reasons, although they were often satisfied of the candidates' unfitness."

$i$. From an attorney and a member of the ssociation: "Very seldom do I follow the information furnished by the bar association because I have almost consistently opposed their theory of recommending judicial candidates. The committee that dispenses the information in the bar as- 
sociation is what might be termed a self-perpetuating committee. Unless a person has an 'in,' I don't believe he gets a good recommendation from the bar, worthy as he may be, and on the other hand if a candidate has a sponsor who is high in the ranks of the bar association it is my honest opinion that he gets an endorsement, in many instances a better endorsement than his ability warrants."

$j$. "The bar association, like any other group of professional or business persons, is obviously constituted in large part of individuals whose views I could not accept. Hence the opinion of that body as a whole is one I would receive with a large measure of caution."

Twenty-two replies implied a lack of confidence in the association by urging sources of information regarding judicial candidates other than the recommendations of the association. These suggestions ranged from "Read the Christian Science Monitor" and "Follow the Democratic Party" to proposing "results of investigation by committees of Departments of Political Science of Chicago institutions" as trustworthy guides.

The Ill-repute of the Bar as a Whole.-The head of a prominent club, which is dedicated to promoting the principles of the Republican party, expressed a personal view, following the November, I932, election, that the public lacks confidence in the lawyers and that the association could use its money to better advantage for new books for its library. He said:

The daily press and the Chicago Bar Association made the fight of their lives to have the Bar Association judicial ticket put over. As usual, the public listened, then went to the polls and forgot all about it. In our humble opinion the Chicago Bar Association should omit trying to teach the public how to vote and for what. The public, we are sorry to say, lack confidence in the lawyers and who can blame them? We would advise the leaders of the Chicago Bar Association to save their money for new books for the library and wait until they are asked by the public to express an opinion on the merits of judicial candidates. We have noticed that volunteered advice is very seldom welcomed by the best of regulated families. Not but what the Bar Association meant well, but the public don't want advice and apparently will not accept it on matters that they believe they are better qualified to answer..$^{x_{4}}$

This same view was expressed by "Skeptical" in an anonymous "Letter to the Editor" of the Chicago Daily News, after the Circuit Court election in June, r933. It said:

.... Perhaps many voters were like the writer so far as the recommendations of the Chicago Bar Association were concerned. Perhaps they wondered who would recommend the Bar Association. Our newspapers are almost daily filled with accounts of the doings of various attorneys in receivership and other cases. To the laymen the newspaper accounts seem to indicate that these attorneys are somewhat "unethical"

I4 Frederick A. Rowe in the Hamiltonian, January, I933, p. I7. The commentator is an attorney and a member of the Chicago, Illinois State, and American Bar Associations. 
in their fees, etc. Is it not a fact that most, if not all of these attorneys, are members of the Bar Association, and if such is the case why doesn't the Bar Association "clean house" and then after displaying to the public "a nice clean washing" come forth with its recommendations to the voters. That method .... would be the best way to influence the voter. Are the judges to whom the Bar Association objected any worse than perhaps many of the Association's members? The writer was unable to decide on whom to vote for, so he passed up the judicial ballot.

In a conference of representatives of civic organizations in which the writer participated, one delegate wrote on the card provided to record requests for marked ballots, speakers, etc.: "Clean up the Bar Association. To that end would be glad to help!"

While these expressions are isolated instances, they undeniably indicate a distrust of the profession widely held by the lay public. The association might have allayed this distrust had it advertised its three year suit to disbar the attorneys in the Sanitary District payroll scandal, its reports on the receivership racket in the state and federal courts, the fact that all disbarment proceedings originating in Chicago result from the work of its Grievance Committee, and that it passed over a first vice-president in selecting a president in I933 because he had been charged with unethical conduct in receivership proceedings! Whatever the motives and evidences underlying the association's recommendations, its purposes will probably always be discounted by a large section of the electorate, as well as impugned by the activities of the criminal-shyster elements within the ranks of the profession. 